\title{
The Reactivity of $\mathrm{MoCl}_{5}$ with Molecules Containing the Alcohol
}

\section{Functionality}

\author{
Fabio Marchetti ${ }^{\mathrm{a}, *}$, Guido Pampaloni ${ }^{\mathrm{a}}$, Stefano Zacchini ${ }^{\mathrm{b}}$
}

${ }^{a}$ Università di Pisa, Dipartimento di Chimica e Chimica Industriale, Via Risorgimento 35, I56126 Pisa, Italy

b Dipartimento di Chimica Industriale "Toso Montanari”, Università di Bologna, Viale Risorgimento 4, I-40136 Bologna, Italy

Received.......; accepted

* Corresponding author. Tel.: +390502219245; Webpage: http://www.dcci.unipi.it/ fabmar/. E-mail address: fabmar@dcci.unipi.it 


\begin{abstract}
The 1:1 molar reaction of $\mathrm{MoCl}_{5}$ with $\mathrm{Cl}\left(\mathrm{CH}_{2}\right)_{2} \mathrm{OH}$, in dichloromethane at room temperature, proceeded with chlorine-oxygen interchange and $\mathrm{HCl}$ release to give $\mathrm{MoOCl}_{3}$ in $65 \%$ yield. The analogous reactions involving ${ }^{\mathrm{i}} \mathrm{PrOH}, \mathrm{MeOH}, L$-menthol and $\mathrm{H}_{2} \mathrm{O}$ gave impure $\mathrm{MoOCl}_{3} \cdot \mathrm{MoCl}_{5}$ reacted with $\mathrm{Me}_{2} \mathrm{~N}\left(\mathrm{CH}_{2}\right)_{2} \mathrm{OH}$ in 1:1 molar ratio affording the 2-chloroammonium salt $\left[\mathrm{Me}_{2} \mathrm{NH}\left(\mathrm{CH}_{2}\right)_{2} \mathrm{Cl}\right]_{2}\left[\mathrm{Mo}_{2} \mathrm{O}_{2} \mathrm{Cl}_{8}\right]$, 1. The reaction of $\mathrm{MoCl}_{5}$ with $\mathrm{MeO}\left(\mathrm{CH}_{2}\right)_{2} \mathrm{OH}$ afforded a mixture of $\quad\left[\mathrm{Mo}\left(\kappa^{2} O, O^{\prime}-\mathrm{O}\left(\mathrm{CH}_{2}\right)_{2} \mathrm{OMe}_{2} \mathrm{Cl}_{2}\right]\left[\mathrm{Mo}_{2} \mathrm{O}_{2} \mathrm{Cl}_{7}\right], \quad \mathbf{2 a}, \quad\right.$ and $\quad\left[\mathrm{Mo}\left(\kappa^{2} O, O^{\prime}-\right.\right.$ $\left.\left.\mathrm{O}\left(\mathrm{CH}_{2}\right)_{2} \mathrm{OMe}\right)_{2} \mathrm{Cl}_{2}\right]\left[\mathrm{MoOCl}_{4}\right], \mathbf{2 b}$. The products $\mathbf{1}, \mathbf{2 a}$ and $\mathbf{2 b}$ were characterized by analytical and spectroscopic techniques, and by X-ray diffractometry. The X-ray structure of $\mathbf{2 b}$ shows weak anion-anion interactions, therefore $2 \mathbf{b}$ might be alternatively viewed as a $\mathrm{Mo}_{2} \mathrm{O}_{2} \mathrm{Cl}_{8}{ }^{2-}$ salt.
\end{abstract}

Keywords: Molybdenum pentachloride, Molybdenum oxido-trichloride, $\mathrm{Cl} / \mathrm{O}$ interchange, Chlorination reaction, X-ray structure

\title{
1. Introduction
}

Molybdenum pentachloride, $\mathrm{MoCl}_{5}$ [1], is a commercial compound which has found increasing employment as catalytic precursor in organic synthesis, due to the easy availability and peculiar chemical properties [2]. Although $\mathrm{MoCl}_{5}$ is highly moisture-sensitive, its use is considered as environmentally acceptable since such halide converts into biocompatible salts in aqueous solution [3]. In agreement with the principle that advancing in the knowledge of the coordination chemistry of transition metal compounds may contribute to the development of the relevant catalysis [4], we have been recently involved in a systematic study of the reactivity of $\mathrm{MoCl}_{5}$ with oxygen atom donors [5]. The present paper focuses on the reactions of $\mathrm{MoCl}_{5}$ with limited amounts of aliphatic alcohols, including compounds bearing an additional functionality (i.e. 2-chloroethanol, N,Ndiethylamino-2-ethanol and 2-methoxyethanol). 
The reactions of high valent, transition metal chlorides with alcohols typically proceed with $\mathrm{HCl}$ release and constitute a convenient entry into mixed chlorido-alkoxide complexes. This feature is common, for instance, to $\mathrm{TiCl}_{4}[6], \mathrm{MCl}_{5}(\mathrm{M}=\mathrm{Nb}, \mathrm{Ta})$ [4], $\mathrm{WCl}_{\mathrm{x}}(\mathrm{x}=5,6)$ [7] and $\mathrm{WOCl}_{4}[8]$, although the reactions between $\mathrm{WCl}_{6}$ and aliphatic alcohols may be accompanied by monoelectron reduction of the tungsten center $[7 \mathrm{a}, \mathrm{b}]$.

Conversely, the chemistry of $\mathrm{MoCl}_{5}$ with alcohols has been little elucidated heretofore, since information available in the literature are sparse and possibly conflicting. In fact, the 1:2 reactions of $\mathrm{MoCl}_{5}$ with $\mathrm{ROH}(\mathrm{R}=\mathrm{Me}, \mathrm{Et})$ at $-78{ }^{\circ} \mathrm{C}$ were claimed to proceed with the "classical" scheme, i.e. $\mathrm{HCl}$ evolution and formation of $\mathrm{MoCl}_{3}(\mathrm{OR})_{2}$ derivatives (see above) [9]. Unambiguous structural characterizations were not provided, instead crystallographically-characterized $\mathrm{Mo}(\mathrm{V})$ chloridoalkoxides have been obtained by treatment of $\mathrm{MoCl}_{5}$ with sodium alkoxides [10] or aliphatic ethers $[5 \mathrm{f}, \mathrm{g}]$. On the other hand, $\mathrm{MoCl}_{5}$ was found to promote the conversion of cyclohexanol into cyclohexyl chloride in stoichiometric conditions [11]. Such chlorinating power might be implicated in the $\mathrm{MoCl}_{5}$-catalyzed amidation of secondary benzyl alcohols [12].

Limberg and co-workers elegantly identified the high-yield product of the room temperature reaction of $\mathrm{MoCl}_{5}$ with a large excess of ethanol in chloroform, that is the dinuclear complex $\left[\mathrm{MoOCl}_{2}(\mu-\mathrm{OEt})(\mu-\mathrm{EtOH})_{0.5}\right]_{2}[13]$. They clearly detected $\mathrm{MoOCl}_{3}(\mathrm{EtOH})$ as intermediate species in the course of the reaction, and proposed $\mathrm{MoOCl}_{3}$ as its immediate precursor [14]. The synthesis of $\mathrm{MoOCl}_{3}$ is not a trivial task: $\mathrm{MoOCl}_{4}$ has been proposed as the starting material, but its use is discouraged by the relatively high cost and the possible prohibitive conditions required for the reduction process [15]. On considering that $\mathrm{MoCl}_{5}$ is a less expensive precursor, Gibson et al. reported the synthesis of $\mathrm{MoOCl}_{3}$ from $\mathrm{MoCl}_{5} / \mathrm{O}\left(\mathrm{SiMe}_{3}\right)_{2}$ [16]; notwithstanding, according to our experience, this method may provide the desired product contaminated by impurities and in moderate yield only. In the course of our exploration of the chemistry of $\mathrm{MoCl}_{5}$ with oxygen donors, we have encountered a number of reactions proceeding with intermediate formation of $\mathrm{MoOCl}_{3}$ 
$[5 \mathrm{a}, \mathrm{b}, \mathrm{c}, \mathrm{e}]$; attempts to isolate this latter have been sometimes successful but, unfortunately, the procedures generally lead to a low purity product. The results reported herein include an alternative, convenient strategy for the preparation of $\mathrm{MoOCl}_{3}$.

The reactions described in the following have been carried out at room temperature in dichloromethane or chloroform, which are commonly considered as scarcely coordinating solvents [17], in strictly anhydrous conditions. The main metal products have been isolated in the solid state and characterized by different techniques and by X-ray diffractometry when possible. NMR analyses have been carried out in order to elucidate the identity of the compounds derived from the eventual activation of the organic material.

\section{Results and Discussion}

The 1:1 molar reaction of $\mathrm{MoCl}_{5}$ with 2-chloroethanol, in dichloromethane at room temperature, afforded after work-up $\mathrm{MoOCl}_{3}$ in $c a .65 \%$ yield (Equation 1). According to IR spectroscopy and elemental analysis, the product was obtained with a good degree of purity in the cited conditions. The IR stretching vibration was observed at $1005 \mathrm{~cm}^{-1}$, coherently with the literature [15a]. The reaction took place with $\mathrm{HCl}$ evolution and quantitative formation of $\mathrm{Cl}\left(\mathrm{CH}_{2}\right)_{2} \mathrm{Cl}$ (detected by $\mathrm{NMR}$, see Experimental for details).

$\mathrm{MoCl}_{5}+\mathrm{ClCH}_{2} \mathrm{CH}_{2} \mathrm{OH} \rightarrow \mathrm{MoOCl}_{3}+\mathrm{ClCH}_{2} \mathrm{CH}_{2} \mathrm{Cl}+\mathrm{HCl}$

The formation of $\mathrm{MoOCl}_{3}$ in the course of the interaction of $\mathrm{MoCl}_{5}$ with aliphatic alcohols was previously conjectured but never clearly recognized (see Introduction) [14]. In order to see whether the process reported in Eqn. 1 had general character or not, we studied the 1:1 reactions of $\mathrm{MoCl}_{5}$ with a series of $\mathrm{ROH}$ compounds $(\mathrm{R}=$ alkyl chain, $\mathrm{H})$, in analogous conditions. All of these reactions produced hydrogen chloride, moreover isopropyl chloride was clearly recognized in the 
$\mathrm{MoCl}_{5} / \mathrm{PrOH}$ system. We were able to isolate $\mathrm{MoOCl}_{3}$ from the reactions with water, isopropanol, methanol and $L$-menthol, however variable amounts of ineliminable byproducts were found in all of the cases.

With the aim of extending the present study to the reactions of $\mathrm{MoCl}_{5}$ with organic molecules bearing additional functionalities beyond the alcoholic one, we moved to consider a series of 2aminoalcohols and one 2-alkoxy-alcohol. Hence, the 1:1 molar reaction between $\mathrm{MoCl}_{5}$ and $\mathrm{Me}_{2} \mathrm{~N}\left(\mathrm{CH}_{2}\right)_{2} \mathrm{OH}$ furnished, after work-up, the salt $\left[\mathrm{Me}_{2} \mathrm{NH}\left(\mathrm{CH}_{2}\right)_{2} \mathrm{Cl}\right]_{2}\left[\mathrm{Mo}_{2} \mathrm{O}_{2} \mathrm{Cl}_{8}\right], \mathbf{1}$, as a highlymoisture sensitive material (Scheme 1).

\section{Scheme 1 about here}

Compound 1 was characterized by elemental analysis, IR and NMR spectroscopy. Moreover, the Xray structure could be ascertained: it is shown in Figure 1, while relevant bond lengths and angles are reported in Table 1. Compound $\mathbf{1}$ is an ionic solid, composed by $\left[\mathrm{Me}_{2} \mathrm{NH}\left(\mathrm{CH}_{2}\right)_{2} \mathrm{Cl}\right]^{+}$cations and $\left[\mathrm{Mo}_{2} \mathrm{O}_{2} \mathrm{Cl}_{8}\right]^{2-}$ anions. The structure of the $\left[\mathrm{Me}_{2} \mathrm{NH}\left(\mathrm{CH}_{2}\right)_{2} \mathrm{Cl}\right]^{+}$cation is unprecedented, although the crystallographic characterizations of miscellaneous salts of the closely related $\left[\mathrm{R}_{2} \mathrm{NH}\left(\mathrm{CH}_{2}\right)_{2} \mathrm{Cl}\right]^{+}$ cations $\left(\mathrm{R}=\mathrm{Et},{ }^{\mathrm{i}} \mathrm{Pr}, \mathrm{CH}_{2} \mathrm{Ph}\right)$ have been reported in the literature [18]. The bonding parameters of the cation, in 1, are in keeping with a $s p^{3}$ hybridization of all $\mathrm{C}$ and $\mathrm{N}$ atoms [19].

The $\left[\mathrm{Mo}_{2} \mathrm{O}_{2} \mathrm{Cl}_{8}\right]^{2-}$ anion is located on an inversion centre and, therefore, only half of it is present within the asymmetric unit of the unit cell. The anion is dimeric, approximately consisting of two edge-sharing octahedra, as previously recognized on miscellaneous salts of the same $\left[\mathrm{Mo}_{2} \mathrm{O}_{2} \mathrm{Cl}_{8}\right]^{2-}$ [20]. More precisely, the molybdenum centre displays a distorted octahedral geometry, being bonded to one oxido, three terminal and two bridging $\mathrm{Cl}$ ligands. The $\mathrm{Mo}(1)-\mathrm{O}(1)$ bond [1.6513(17) $\AA$ ] reveals a strong $\pi$-character, as expected for a $\mathrm{Mo}^{\mathrm{V}}=\mathrm{O}$ unit [5]. The chloride bridges are very asymmetric, in fact $\mathrm{Mo}(1)-\mathrm{Cl}(3)$ [2.3944(6) $\AA]$, trans to $\mathrm{Cl}(1)$, is considerably shorter than 
$\mathrm{Mo}(1)-\mathrm{Cl}\left(3 \_1\right)[2.866(2) \AA]$, trans to the stronger oxido ligand. The same asymmetry was found in all the previous structures of the $\left[\mathrm{Mo}_{2} \mathrm{O}_{2} \mathrm{Cl}_{8}\right]^{2-}$ anion, and it will be further discussed below.

Hydrogen bonds are present within the structure of $\mathbf{1}$, between the cation and anion, involving $\mathrm{N}(1)-\mathrm{H}(1)$ as donor and $\mathrm{Cl}(2)[\mathrm{N}(1)-\mathrm{H}(1)$ 0.857(16) $\AA$; $\mathrm{H}(1) \cdots \mathrm{Cl}(2) 2.726(19) \AA \AA$; $\mathrm{N}(1) \cdots \mathrm{Cl}(2)$

$\left.3.460(2) \AA \AA ;<\mathrm{N}(1) \mathrm{H}(1) \mathrm{Cl}(2) \quad 145(2)^{\circ}\right]$ and $\mathrm{Cl}\left(4 \_1\right)\left[\mathrm{N}(1)-\mathrm{H}(1) \quad 0.857(16) \AA \AA \mathrm{H}(1) \cdots \mathrm{Cl}\left(4 \_1\right)\right.$ 2.68(2) $\left.\AA ; \mathrm{N}(1) \cdots \mathrm{Cl}\left(4 \_1\right) 3.276(2) \AA ;<\mathrm{N}(1) \mathrm{H}(1) \mathrm{Cl}\left(4 \_1\right) 127.8(19)^{\circ}\right]$ as acceptors.

\section{Figure 1 about here}

\section{Table 1 about here}

Salient features of the IR spectrum of $\mathbf{1}$ (in the solid state) are the absorptions due to the $\mathrm{N}-\mathrm{H}$ and $\mathrm{Mo}=\mathrm{O}$ moieties, respectively at 3122 and $992 \mathrm{~cm}^{-1}$. The latter value matches what previously reported for $\mathrm{Mo}(\mathrm{V})$ oxido-chloride derivatives. ${ }^{5}$ The NMR spectra $\left(\mathrm{CD}_{3} \mathrm{CN}\right.$ solution) exhibit broad resonances related to the cation. The $N$-bound proton has been found at $7.80 \mathrm{ppm}$, whereas the $N$ methyl substituents resonate at $2.90\left({ }^{1} \mathrm{H}\right)$ and $45.0\left({ }^{13} \mathrm{C}\right) \mathrm{ppm}$.

The synthesis of $\mathbf{1}$ is the result of chlorine-oxygen interchange between the molybdenum chloride and the organic compound, presumably accompanied by $\mathrm{H}^{+}$intramolecular migration. According to IR and elemental analysis data, the 1:1 reactions of $\mathrm{MoCl}_{5}$ with $\mathrm{Et}_{2} \mathrm{~N}\left(\mathrm{CH}_{2}\right)_{2} \mathrm{OH}$ and $\mathrm{PhNH}\left(\mathrm{CH}_{2}\right)_{2} \mathrm{OH}$ proceeded in a similar way (see Experimental for details). In fact the solid products were tentatively identified, by means of IR spectroscopy and analytical data, as ammonium salts of general formula $\left[\mathrm{R}_{2} \mathrm{NH}\left(\mathrm{CH}_{2}\right)_{2} \mathrm{Cl}\right]_{2}\left[\mathrm{Mo}_{2} \mathrm{O}_{2} \mathrm{Cl}_{8}\right](\mathrm{R}=\mathrm{Et}, \mathrm{Ph})$. Nevertheless, unambiguous characterization was not possible due to the absence of X-ray evidence.

The reaction of $\mathrm{MoCl}_{5}$ with a three fold excess of 2-methoxyethanol led to the isolation of a mixture of two ionic products, i.e. $\left[\mathrm{Mo}\left(\kappa^{2} O, O^{\prime}-\mathrm{O}\left(\mathrm{CH}_{2}\right)_{2} \mathrm{OMe}\right)_{2} \mathrm{Cl}_{2}\right]\left[\mathrm{Mo}_{2} \mathrm{O}_{2} \mathrm{Cl}_{7}\right]$, 2a, and $\left[\mathrm{Mo}\left(\kappa^{2} O, O^{\prime}-\right.\right.$ $\left.\left.\mathrm{O}\left(\mathrm{CH}_{2}\right)_{2} \mathrm{OMe}\right)_{2} \mathrm{Cl}_{2}\right]\left[\mathrm{MoOCl}_{4}\right]$, 2b, being 2a largely prevalent (Scheme 2). The reaction performed 
with different molar ratios, i.e. 2-methoxyethanol/Mo $=1$ or 2 , afforded complicated mixtures of non identified metal products; however, IR analyses indicated the formation of the $\mathrm{Mo}=\mathrm{O}$ moiety (strong band around $990 \mathrm{~cm}^{-1}$ ).

\section{Scheme 2 about here}

Compounds 2a-b were separated by fractional crystallization and characterized by elemental analysis, IR spectroscopy (the IR spectra exhibit a strong band due to the anion $\mathrm{Mo}=\mathrm{O}$ moiety, at $c a$. $1000 \mathrm{~cm}^{-1}$ [5]) and X-ray diffractometry. The ORTEP views are shown in Figures 2 and 3, with the relevant bonding parameters reported in Tables 2 and 3.

\section{Figure 2 about here}

\section{Table 2 about here}

The structure of the $\left[\mathrm{Mo}_{2} \mathrm{O}_{2} \mathrm{Cl}_{7}\right]^{-}$anion present in $\mathbf{2 a}$ is very similar to the ones previously reported for the same anion associated with different cations [21]. It consists of two face-sharing octahedra with each Mo-centre bonded to one oxido, two terminal and three bridging chloride ligands. The oxido ligands exert a strong trans influence and, therefore, the $\mathrm{Mo}(2)-\mathrm{Cl}(5)[2.772(2)$ $\AA]$ and $\mathrm{Mo}(3)-\mathrm{Cl}(6)[2.777(2) \AA]$ bonds are considerably elongated compared to the other bridging Mo-Cl interactions [2.4096(19)-2.489(2) $\AA]$. These, in turn, are longer respect to the terminal Mo-Cl bonds [2.299(2)-2.322(2) Å].

The $\left[\mathrm{Mo}\left(\kappa^{2} \mathrm{O}, \mathrm{O}^{\prime}-\mathrm{O}\left(\mathrm{CH}_{2}\right)_{2} \mathrm{OMe}\right)_{2} \mathrm{Cl}_{2}\right]^{+}$cation is completely unprecedented. It consists of a distorted octahedral molybdenum centre bonded to two chloride ligands in relative cis position as well as two chelating $\left[\mathrm{OCH}_{2} \mathrm{CH}_{2} \mathrm{OMe}\right]^{-}$anionic ligands. These chelating ligands bind to $\mathrm{Mo}(1)$ via 
an alkoxido group and an ether one. In view of the anionic nature of the former, $\mathrm{Mo}(1)-\mathrm{O}(1)$ $[1.828(5) \AA]$ and $\mathrm{Mo}(1)-\mathrm{O}(3)[1.816(5) \AA]$ are significantly shorter than $\mathrm{Mo}(1)-\mathrm{O}(2)[2.216(5) \AA]$ and $\mathrm{Mo}(1)-\mathrm{O}(4)[2.207(5) \AA]$.

Figure 3 about here

Table 3 about here

The structure of $\mathbf{2} \mathbf{b}$ consists of an ionic packing of $\left[\mathrm{Mo}\left(\kappa^{2} \mathrm{O}, \mathrm{O}^{\prime}-\mathrm{O}\left(\mathrm{CH}_{2}\right)_{2} \mathrm{OMe}\right)_{2} \mathrm{Cl}_{2}\right]^{+}$cations and $\left[\mathrm{MoOCl}_{4}\right]^{-}$anions. The former cation is identical to the one found in $\mathbf{2 a}$ and, therefore, it will not be discussed any further. The $\left[\mathrm{MoOCl}_{4}\right]^{-}$anion displays a distorted square-pyramidal structure, as previously found in other $\left[\mathrm{MoOCl}_{4}\right]^{-}$salts $[21 \mathrm{~b}, 14,20 \mathrm{~d}, 22]$. It is noteworthy that, within the solid state structure of $\mathbf{2 b}$, two weak $\mathrm{Mo} \cdots \mathrm{Cl}$ contacts $[2.956(2) \AA]$ are present between two adjacent $\left[\mathrm{MoOCl}_{4}\right]^{-}$anions, involving $\mathrm{Mo}(1)-\mathrm{Cl}\left(3 \_1\right)$ and $\mathrm{Mo}\left(1_{-} 1\right)-\mathrm{Cl}(3)$ [symmetry operation used: $-\mathrm{x}$, y, 0.5-z] (Figure 4).

\section{Figure 4 about here}

Depending on whether such $\mathrm{Mo} \cdots \mathrm{Cl}$ contacts are considered as bonds or not, the anion of $\mathbf{2} \mathbf{b}$ would be better described either as the dinuclear $\left[\mathrm{Mo}_{2} \mathrm{O}_{2} \mathrm{Cl}_{8}\right]^{2-}$ or the mononuclear $\left[\mathrm{MoOCl}_{4}\right]^{-}$. A search on the Cambridge Structural Database for the $\left[\mathrm{MoOCl}_{4}\right]^{-}$anion has resulted in different entries, which may be grouped into three categories: (A) "isolated" [ $\left.\mathrm{MoOCl}_{4}\right]^{-}$anions [21b,22a-b]; (B) $\left[\mathrm{MoOCl}_{4}\right]^{-}$anions displaying a weak intermolecular interaction with a donor atom of the cation or the co-crystallized solvent molecule $[14,22 \mathrm{c}]$; (C) $\left[\mathrm{MoOCl}_{4}\right]^{-}$anions showing a weak $\mathrm{Mo}{ }^{\cdots} \mathrm{Cl}$ interaction with adjacent $\left[\mathrm{MoOCl}_{4}\right]^{-}[20 \mathrm{~d}]$. The only entry of category $(\mathrm{C})$ is represented by $\left[\mathrm{Me}_{2} \mathrm{C}=\mathrm{NH}_{2}\right]\left[\mathrm{MoOCl}_{4}\right][20 \mathrm{~d}]$, where the anions interact as pairs to give centrosymmetric 
dinuclear units containing an asymmetric $\mathrm{Cl}$ bridge [shortest intermolecular $\mathrm{Mo} \cdots \mathrm{Cl}$ contact $=$ $3.08 \AA]$. On the other hand, $\left[\mathrm{F}_{3} \mathrm{CC}\left(\mathrm{NH}_{2}\right)_{2}\right]_{2}\left[\mathrm{Mo}_{2} \mathrm{O}_{2} \mathrm{Cl}_{8}\right]$ [23], showing the longest Mo- $\mu-\mathrm{Cl}$ distance $[2.928(1) \AA]$ similar to that observed in $\mathbf{2 b}$, has been described in the Cambridge Structural Database (Code KUGVEN) as a dimeric $\left[\mathrm{Mo}_{2} \mathrm{O}_{2} \mathrm{Cl}_{8}\right]^{2-}$ salt. On account of the fact that the sum of the covalent radii of $\mathrm{Mo}$ and $\mathrm{Cl}$ is $2.46 \AA$ [24], we prefer to describe the anion in $\mathbf{2 b}$ as a monomer.

In order to collect information about the possible degradation pathways involving the organic reactant, we analyzed an aliquot of the mixture $\mathrm{MoCl}_{5} / 2$-methoxyethanol by GC-MS. The analysis revealed the presence of $\mathrm{MeO}\left(\mathrm{CH}_{2}\right)_{2} \mathrm{Cl}$, together with minor amount of $\mathrm{MeCl}$. Moreover, the formation of $\mathrm{HCl}$ was detected by silver chloride precipitation test (see Experimental). According to these features, the interaction of $\mathrm{MoCl}_{5}$ with a portion of $\mathrm{MeO}\left(\mathrm{CH}_{2}\right)_{2} \mathrm{OH}$ takes place with $\mathrm{Cl} / \mathrm{O}$ interchange, in analogy with what discussed above for other alcohols. This process gives reason for the formation of the $[\mathrm{Mo}=\mathrm{O}]$ containing anions in $\mathbf{2 a , b}$, and of $\mathrm{MeO}\left(\mathrm{CH}_{2}\right)_{2} \mathrm{Cl}$ and some $\mathrm{HCl}$ (Scheme 3a). Otherwise another portion of $\mathrm{MeO}\left(\mathrm{CH}_{2}\right)_{2} \mathrm{OH}$ reacts with the metal centre via $\mathrm{HCl}$ release, thus resulting in the formation of the cation (Scheme 3b). Nevertheless a competitive, minor pathway appears to be operative, consisting of methyl-O bond cleavage and consequent release of methyl chloride (Scheme 3c). We could not collect further information needed to fully elucidate this latter process.

\section{Scheme 3 about here}

\section{Conclusions}

In this paper, we have presented the results of the reactions of $\mathrm{MoCl}_{5}$ with a series of molecules containing the alcohol functionality. The reactions usually proceed with $\mathrm{Cl} / \mathrm{O}$ interchange and $\mathrm{HCl}$ release to give the $\mathrm{Mo}=\mathrm{O}$ unit. In particular, the reaction of $\mathrm{MoCl}_{5}$ with 
$\mathrm{Cl}\left(\mathrm{CH}_{2}\right)_{2} \mathrm{OH}$ may represent a new convenient strategy for the preparation of $\mathrm{MoOCl}_{3}$. $\mathrm{HCl}$ produced by the $\mathrm{MoCl}_{5} / 2$-aminoethanol system appears to be trapped by the amino group, thus resulting in the formation of the relevant 2-chloroammonium $\left[\mathrm{MoOCl}_{4}\right]^{-}$salt. The reaction of $\mathrm{MoCl}_{5}$ with 2-methoxyethanol seems to be characterized by a limited degree of selectivity, however $\mathrm{Cl} / \mathrm{O}$ interchange and $\mathrm{HCl}$ production still remain operative; the products isolated in this case are ionic compounds in which the cation comprises the bidentate $\left[\mathrm{MeO}\left(\mathrm{CH}_{2}\right)_{2} \mathrm{O}\right]^{-}$ligand. The results presented herein contribute to expand the knowledge on the coordination chemistry of the environmentally-friendly $\mathrm{MoCl}_{5}$, and might help the progress of the relevant catalytic processes.

\section{Experimental}

\subsection{General procedures}

Warning: All the metal products reported in this paper are highly moisture-sensitive, thus rigorously anhydrous conditions were required for the reaction and crystallization procedures. The reaction vessels were oven dried at $150^{\circ} \mathrm{C}$ prior to use, evacuated $\left(10^{-2} \mathrm{mmHg}\right)$ and then filled with argon. $\mathrm{MoCl}_{5}$ was purchased from Strem (99.6\% purity) and stored in sealed tubes under argon atmosphere. Once isolated, the metal products were conserved in sealed glass tubes under argon. The organic reactants were commercial products (Sigma-Aldrich) stored under argon atmosphere as received. Solvents (Sigma-Aldrich) were distilled before use from appropriate drying agents. Infrared spectra were recorded at $298 \mathrm{~K}$ on a FT IR-Perkin Elmer Spectrometer, equipped with a UATR sampling accessory. NMR spectra were recorded at $293 \mathrm{~K}$ on a Bruker Avance DRX400 instrument equipped with a BBFO broadband probe. The chemical shifts were referenced to the non-deuterated aliquot of the solvent. GC/MS analyses were performed on a HP6890 instrument, interfaced with a MSD-HP5973 detector and equipped with a Phenonex Zebron column. Carbon, hydrogen and nitrogen analyses were performed on Carlo Erba mod. 1106 instrument. The chloride content was determined by the Mohr method [25] on solutions 
prepared by dissolution of the solids in aqueous $\mathrm{KOH}$ at boiling temperature, followed by cooling to room temperature and addition of diluted $\mathrm{HNO}_{3}$ up to neutralization. Molybdenum was analysed according to the method proposed by Crouthamel e Johnson [26], upon dissolution of the solid samples (30-60 mg) in $100 \mathrm{~mL}$ of $4 \mathrm{M} \mathrm{HCl}$; the calibration curve was obtained using $\left(\mathrm{NH}_{4}\right)_{6} \mathrm{Mo}_{7} \mathrm{O}_{24} \cdot 4 \mathrm{H}_{2} \mathrm{O}$ as standard $\left(\mathrm{R}^{2}=0.999\right)$.

4.2. Reactions of $\mathrm{MoCl}_{5}$ with $\mathrm{ROH}\left(\mathrm{R}=\mathrm{ClCH}_{2} \mathrm{CH}_{2},{ }^{i} \mathrm{Pr}, \mathrm{H}\right)$ : synthesis of $\mathrm{MoOCl}_{3}$. General procedure: A suspension of $\mathrm{MoCl}_{5}(0.400 \mathrm{~g}, 1.46 \mathrm{mmol})$ in $\mathrm{CH}_{2} \mathrm{Cl}_{2}(15 \mathrm{~mL})$ was treated with the appropriate oxygen compound $(1.45 \mathrm{mmol})$. The mixture was stirred at room temperature for $4 \mathrm{~d}$. The final mixture was concentrated up to $c a .3 \mathrm{~mL}$ and filtrated in order to isolate a dark-brown solid. The solid was washed with $\mathrm{CHCl}_{3}(30 \mathrm{~mL})$ and pentane $(30 \mathrm{~mL})$, and then dried under vacuo.

In a different experiment, $\mathrm{MoCl}_{5}(0.110 \mathrm{~g}, 0.403 \mathrm{mmol}), \mathrm{CD}_{2} \mathrm{Cl}_{2}(0.70 \mathrm{~mL}), \mathrm{CHCl}_{3}(0.032 \mathrm{~mL}$, $0.398 \mathrm{mmol})$ and the appropriate oxygen compound $(0.403 \mathrm{mmol})$ were introduced into an NMR tube in the order given. The tube was sealed and stored at room temperature for one week; ${ }^{1} \mathrm{H}$ NMR analysis was carried out subsequently. When the tube was opened, gas $(\mathrm{HCl})$ release was observed: bubbling the gas into an aqueous solution of $\mathrm{AgNO}_{3}$ determined the precipitation of $\mathrm{AgCl}$.

a) From $\mathrm{MoCl}_{5} / \mathrm{Cl}\left(\mathrm{CH}_{2}\right)_{2} \mathrm{OH}$. Yield: $0.207 \mathrm{~g}, 65 \%$. Anal. Calcd. for $\mathrm{Cl}_{3} \mathrm{MoO}$ : $\mathrm{Cl}, 48.72$; $\mathrm{Mo}$, 43.95. Found: $\mathrm{Cl}, 48.40$; Mo, 44.10. IR (solid state): $v=1005 \mathrm{vs}\left(v_{\mathrm{Mo}}=\mathrm{O}\right) \mathrm{cm}^{-1} \cdot{ }^{1} \mathrm{H}$ NMR analysis: $\mathrm{CHCl}_{3}$ and $\mathrm{Cl}\left(\mathrm{CH}_{2}\right)_{2} \mathrm{Cl}$ (ratio 1:0.9).

b) From $\mathrm{MoCl}_{5} /{ }^{i} \mathrm{PrOH}$. Yield: $0.188 \mathrm{~g}, 59 \% . \mathrm{MoOCl}_{3}$ was isolated contaminated by impurities. ${ }^{1} \mathrm{H}$ NMR analysis: $\mathrm{CHCl}_{3}$ and ${ }^{i} \mathrm{PrCl}$ (ratio 1:0.8).

c) From $\mathrm{MoCl}_{5} / \mathrm{H}_{2} \mathrm{O}$. Yield: $0.153 \mathrm{~g}, 48 \% . \mathrm{MoOCl}_{3}$ was isolated contaminated by impurities.

d) From $\mathrm{MoCl}_{5} /$ menthol. Yield: $0.115 \mathrm{~g}, 36 \%$. $\mathrm{MoOCl}_{3}$ was isolated contaminated by impurities. 
e) From $\mathrm{MoCl}_{5} / \mathrm{MeOH}$. Yield: $0.182 \mathrm{~g}, 57 \%$. $\mathrm{MoOCl}_{3}$ was isolated contaminated by impurities.

4.3. Reactions of $\mathrm{MoCl}_{5}$ with aminoalcohols. Synthesis of $\left[\mathrm{Me}_{2} \mathrm{NHCH}_{2} \mathrm{CH}_{2} \mathrm{Cl}_{2}\left[\mathrm{Mo}_{2} \mathrm{O}_{2} \mathrm{Cl}_{8}\right]\right.$, 1. A suspension of $\mathrm{MoCl}_{5}(0.350 \mathrm{~g}, 1.28 \mathrm{mmol})$ in $\mathrm{CH}_{2} \mathrm{Cl}_{2}(15 \mathrm{~mL})$ was treated with $\left.\mathrm{Me}_{2} \mathrm{~N}_{(\mathrm{CH}}\right)_{2} \mathrm{OH}$ $(0.135 \mathrm{~mL}, 1.34 \mathrm{mmol})$. The mixture was stirred at room temperature for $72 \mathrm{~h}$, then it was concentrated up to $c a .3 \mathrm{~mL}$. Addition of hexane $(30 \mathrm{~mL})$ determined the precipitation of a yellow solid from a light-brown solution. The solid was washed with pentane $(20 \mathrm{~mL})$ and dried in vacuo. Yield: 0.311 g, 67\%. Anal. Calcd for $\mathrm{C}_{4} \mathrm{H}_{11} \mathrm{Cl}_{5} \mathrm{MoNO}$ : C, 13.26; H, 3.06; N, 3.87; Cl, 48.92 . Found: C, 13.02; H, 2.94; N, 3.95; Cl, 48.59. IR (solid state): $v=3122 \mathrm{~m}\left(v_{\mathrm{N}-\mathrm{H}}\right), 3078 \mathrm{~m}-\mathrm{sh}$, $3032 \mathrm{w}-\mathrm{sh}, 2742 \mathrm{w}, 1602 \mathrm{~m}, 1477 \mathrm{~m}, 1455 \mathrm{vs}, 1438 \mathrm{~m}-\mathrm{s}, 1413 \mathrm{w}, 1388 \mathrm{~m}, 1365 \mathrm{~m}, 1310 \mathrm{w}, 1280 \mathrm{w}$, $1160 \mathrm{w}, 1129 \mathrm{w}, 1055 \mathrm{w}, 1043 \mathrm{w}, 1003 \mathrm{~s}, 992 \mathrm{vs}\left(\mathrm{v}_{\mathrm{Mo}}=\mathrm{O}\right), 973 \mathrm{~s}, 926 \mathrm{~s}, 897 \mathrm{w}, 758 \mathrm{w}-\mathrm{m}, 676 \mathrm{~s} \mathrm{~cm}{ }^{-1} .{ }^{1} \mathrm{H}$ NMR $\left(\mathrm{CD}_{3} \mathrm{CN}\right): \delta=7.80(\mathrm{br}, 1 \mathrm{H}, \mathrm{NH}), 3.90\left(\mathrm{br}, 2 \mathrm{H}, \mathrm{ClCH}_{2}\right), 3.44$ (br, $\left.2 \mathrm{H}, \mathrm{NCH}_{2}\right), 2.90$ ppm (s, $\left.6 \mathrm{H}, \mathrm{NMe}_{2}\right) .{ }^{13} \mathrm{C}\left\{{ }^{1} \mathrm{H}\right\} \mathrm{NMR}\left(\mathrm{CD}_{3} \mathrm{CN}\right): \delta=59.8\left(\mathrm{NCH}_{2}\right), 45.0\left(\mathrm{NMe}_{2}\right), 38.4 \mathrm{ppm}\left(\mathrm{ClCH}_{2}\right)$. Crystals of 1 suitable for X-ray analysis were collected from a $\mathrm{CH}_{2} \mathrm{Cl}_{2}$ solution layered with hexane and stored at $-30{ }^{\circ} \mathrm{C}$ for $7 \mathrm{~d}$.

The reactions of $\mathrm{MoCl}_{5}$ with $\mathrm{Et}_{2} \mathrm{~N}\left(\mathrm{CH}_{2}\right)_{2} \mathrm{OH}$ and $\mathrm{PhNH}\left(\mathrm{CH}_{2}\right)_{2} \mathrm{OH}$ were performed by procedures analogous to that described for the synthesis of $\mathbf{1}$.

From $\mathrm{MoCl}_{5}(0.340 \mathrm{~g}, 1.24 \mathrm{mmol})$ and $\mathrm{Et}_{2} \mathrm{~N}\left(\mathrm{CH}_{2}\right)_{2} \mathrm{OH}(0.170 \mathrm{~mL}, 1.28 \mathrm{mmol})$ : ochre-yellow solid, yield 0.271 g. Anal. Calcd for $\mathrm{C}_{6} \mathrm{H}_{15} \mathrm{Cl}_{5} \mathrm{MoNO}$ : C, 18.46; H, 3.87; N, 3.59; Cl, 45.41 . Found: C, 18.70; H, 3.59; N, 3.68; Cl, 45.89. IR (solid state): $v=3115 \mathrm{~m}\left(v_{\mathrm{N}-\mathrm{H}}\right), 2985 \mathrm{w}, 2797 \mathrm{w}$, $1670 \mathrm{w}, 1456 \mathrm{~m}, 1398 \mathrm{~m}, 1260 \mathrm{w}, 1227 \mathrm{w}, 1170 \mathrm{w}, 1121 \mathrm{w}, 1047 \mathrm{~m}, 1027 \mathrm{~s}, 992 \mathrm{vs}\left(\mathrm{v}_{\mathrm{Mo}}=\mathrm{O}\right), 942 \mathrm{~m}$, 920s, 874w-m, 818w-m, 797m, 736w cm $\mathrm{cm}^{-1}$.

From $\mathrm{MoCl}_{5}(0.340 \mathrm{~g}, 1.24 \mathrm{mmol})$ and $\mathrm{PhNH}\left(\mathrm{CH}_{2}\right)_{2} \mathrm{OH}(0.180 \mathrm{~g}, 1.31 \mathrm{mmol})$ : brown-red solid, yield 0.331 g. Anal. Calcd for $\mathrm{C}_{8} \mathrm{H}_{11} \mathrm{Cl}_{5}$ MoNO: C, 23.41; H, 2.70; N, 3.41; Cl, 43.19. Found: C, 
23.28; H, 2.82; N, 3.53; Cl, 43.03. IR (solid state): $v=3340 \mathrm{~m}-\mathrm{br}\left(v_{\mathrm{N}-\mathrm{H}}\right), 3108 \mathrm{w}, 3058 \mathrm{w}, 2970 \mathrm{w}$, $1595 \mathrm{w}-\mathrm{m}, 1494 \mathrm{~m}, 1478 \mathrm{~m}, 1452 \mathrm{~m}, 1433 \mathrm{w}-\mathrm{m}, 1372 \mathrm{~m}, 1263 \mathrm{~m}, 1212 \mathrm{w}, 1158 \mathrm{w}, 1062 \mathrm{vs}, 990 \mathrm{vs}$ $(\mathrm{Mo}=\mathrm{O}), 930 \mathrm{~m}-\mathrm{s}, 810 \mathrm{~m}, 759 \mathrm{~s}, 732 \mathrm{~s}, 691 \mathrm{vs} \mathrm{cm}^{-1}$

4.4. Reaction of $\mathrm{MoCl}_{5}$ with $\mathrm{MeO}\left(\mathrm{CH}_{2}\right)_{2} \mathrm{OH}$. Synthesis of $\left[\mathrm{Mo}\left(\mathrm{K}^{2} \mathrm{O}, \mathrm{O}^{\prime}-\right.\right.$ $\left.\mathrm{O}\left(\mathrm{CH}_{2}\right)_{2} \mathrm{OMe}_{2} \mathrm{Cl}_{2}\right]\left[\mathrm{Mo}_{2} \mathrm{O}_{2} \mathrm{Cl}_{7}\right], \quad 2 \boldsymbol{a}$, and $\left[\mathrm{Mo}\left(\kappa^{2} \mathrm{O}, \mathrm{O}^{\prime}-\mathrm{O}\left(\mathrm{CH}_{2}\right)_{2} \mathrm{OMe}_{2} \mathrm{Cl}_{2}\right]\left[\mathrm{MoOCl}_{4}\right], 2 \boldsymbol{b}\right.$. $\mathrm{MoCl}_{5}$ $(0.300 \mathrm{~g}, 1.10 \mathrm{mmol})$ was added to a solution of $\mathrm{MeO}\left(\mathrm{CH}_{2}\right)_{2} \mathrm{OH}(0.260 \mathrm{~mL}, 3.30 \mathrm{mmol})$ in $\mathrm{CH}_{2} \mathrm{Cl}_{2}(15 \mathrm{~mL})$. Gas $(\mathrm{HCl})$ release was observed in few minutes, then the mixture was stirred for additional 18 hours. Bubbling the gas into an aqueous solution of $\mathrm{AgNO}_{3}$ determined precipitation of a white solid $(\mathrm{AgCl})$. GC-MS analysis was carried out on an aliquot of the final bright-green solution and revealed the presence of $\mathrm{MeO}\left(\mathrm{CH}_{2}\right)_{2} \mathrm{Cl}$ and $\mathrm{MeCl}$, the former being prevalent. The solution was concentrated up to $c a .3 \mathrm{~mL}$, layered with hexane and stored at $-30^{\circ} \mathrm{C}$. A large crop of green crystals of 2a was collected after $7 \mathrm{~d}$. The mother liquor was maintained at $-30{ }^{\circ} \mathrm{C}$ for additional 20 days, thus minor yield of crystals of $\mathbf{2 b}$ was afforded.

2a (green solid). Yield 0.174 g, 60\%. Anal. Calcd for $\mathrm{C}_{6} \mathrm{H}_{14} \mathrm{Cl}_{9} \mathrm{Mo}_{3} \mathrm{O}_{6}$ : $\mathrm{C}, 9.13 ; \mathrm{H}, 1.79 ; \mathrm{Cl}, 40.44$. Found: C, 9.08; H, 1.73; Cl, 40.52. IR (solid state): $v=2975 \mathrm{w}, 2958 \mathrm{w}, 2897 \mathrm{w}, 1471 \mathrm{w}, 1448 \mathrm{w}$, $1438 \mathrm{w}, 1385 \mathrm{w}-\mathrm{m}, 1339 \mathrm{w}, 1298 \mathrm{w}, 1261 \mathrm{w}-\mathrm{m}, 1249 \mathrm{w}, 1224 \mathrm{~m}, 1171 \mathrm{w}, 1106 \mathrm{~m}, 1089 \mathrm{~m}, 1056 \mathrm{~s}$, $1021 \mathrm{~m}-\mathrm{s}, 984 \mathrm{vs}\left(v_{\mathrm{Mo}=\mathrm{O}}\right), 925 \mathrm{~s}, 910 \mathrm{~s}, 808 \mathrm{~m}, 784 \mathrm{~s}, 671 \mathrm{w} \mathrm{cm} \mathrm{c}^{-1}$.

2b (dark solid). Yield $0.031 \mathrm{~g}, 10 \%$. Anal. Calcd for $\mathrm{C}_{6} \mathrm{H}_{14} \mathrm{Cl}_{6} \mathrm{Mo}_{2} \mathrm{O}_{5}$ : C, 12.63; H, 2.47; Cl, 37.27 . Found: C, 12.44; H, 2.51; Cl, 37.25. IR (solid state) $: v=996 \mathrm{vs}\left(v_{\mathrm{Mo}=\mathrm{O}}\right) \mathrm{cm}^{-1}$

\subsection{X-ray Crystallographic Studies.}

Crystal data and collection details for $\left[\mathrm{CH}_{2} \mathrm{ClCH}_{2} \mathrm{NHMe}_{2}\right]_{2}\left[\mathrm{Mo}_{2} \mathrm{O}_{2} \mathrm{Cl}_{8}\right]$, 1, $\quad\left[\mathrm{Mo}\left(\kappa^{2} O, O^{\prime}-\right.\right.$ $\left.\left.\mathrm{O}\left(\mathrm{CH}_{2}\right)_{2} \mathrm{OMe}\right)_{2} \mathrm{Cl}_{2}\right]\left[\mathrm{Mo}_{2} \mathrm{O}_{2} \mathrm{Cl}_{7}\right]$, 2a, and $\left[\mathrm{Mo}\left(\kappa^{2} \mathrm{O}, \mathrm{O}^{\prime}-\mathrm{O}\left(\mathrm{CH}_{2}\right)_{2} \mathrm{OMe}_{2} \mathrm{Cl}_{2}\right]\left[\mathrm{MoOCl}_{4}\right] \cdot 0.5 \mathrm{CH}_{2} \mathrm{Cl}_{2}\right.$, 
2b $\cdot \mathrm{CH}_{2} \mathrm{Cl}_{2}$, are listed in Table 4. The diffraction experiments were carried out on a Bruker APEX II diffractometer equipped with a CCD detector and using Mo-K $\alpha$ radiation. Data were corrected for Lorentz polarization and absorption effects (empirical absorption correction SADABS). ${ }^{27}$ Structures were solved by direct methods and refined by full-matrix least-squares based on all data using $F^{2}$ [27]. All non-hydrogen atoms were refined with anisotropic displacement parameters. Hatoms were placed in calculated positions and treated isotropically using the 1.2 fold $U_{\text {iso }}$ value of the parent $\mathrm{C}$-atom, apart from $\mathrm{H}(1)$ in $\mathbf{1}$ which was located in the Fourier map and refined isotropically, using the 1.2 fold $U_{\text {iso }}$ value of the parent $\mathrm{N}$ atom. The $\mathrm{N}(1)-\mathrm{H}(1)$ distance of 1 was restrained to $0.89 \AA$ (s.u. 0.02). The $\left[\mathrm{Mo}_{2} \mathrm{O}_{2} \mathrm{Cl}_{8}\right]^{2-}$ anion of $\mathbf{1}$ is located on an inversion centre and, therefore, only half of it is present in the asymmetric unit of the unit cell. Similarly, the $\mathrm{CH}_{2} \mathrm{Cl}_{2}$ molecule of $\mathbf{2} \mathbf{b} \cdot \mathrm{CH}_{2} \mathrm{Cl}_{2}$ is located on a 2 -fold axis.

\section{Insert Table 4 about here.}

Appendix A. Supplementary data. CCDC 993264-993266 contain the supplementary crystallographic data for $\mathbf{1}, \mathbf{2 a}$ and $\mathbf{2 b}$. These data can be obtained free of charge via http://www.ccdc.cam.ac.uk/conts/retrieving.html, or from the Cambridge Crystallographic Data Centre, 12 Union Road, Cambridge CB2 1EZ, UK; fax: (+44) 1223-336-033; or e-mail: deposit@,ccdc.cam.ac.uk.

\section{References}

[1] Molybdenum pentachloride is dinuclear in the solid state (Beck, J.; Wolf, F. Acta Crystallogr., Sect. B: Struct. Sci. 53 (1997) 895). It will be mentioned by the empirical formula $\mathrm{MoCl}_{5}$ throughout this paper. 
[2] (a) Waldvogel, S. R.; Trosien, S. Chem. Commun. 48 (2012) 9109, and references therein; (b) Schubert, M.; Leppin, J.; Wehming, K.; Schollmeyer, D.; Heinze, K.; Waldvogel, S. R. Angew. Chem. Int. Ed. 53 (2014) 2494.

[3] Grzybowski, M.; Skonieczny, K.; Butenschön, H.; Gryko, D. T. Angew. Chem. Int. Ed. 52 (2013) 9900.

[4] Marchetti, F.; Pampaloni, G. Chem. Commun. 48 (2012) 635, and references therein.

[5] (a) Favero, L.; Marchetti, F.; Pampaloni, G.; Zacchini, S. Dalton Trans. 43 (2014) 495; (b) Marchetti, F.; Pampaloni, G.; Zacchini, S. Dalton Trans. 42 (2013) 2477; (c) Dolci, S.; Marchetti, F.; Pampaloni, G.; Zacchini, S. Eur. J. Inorg. Chem. 8 (2013) 1371; (d) Marchetti, F.; Pampaloni, G.; Zacchini, S. RSC Advances 3 (2013) 10007; (e) Hayatifar, M.; Marchetti, F.; Pampaloni, G.; Pinzino, C.; Zacchini, S. Polyhedron 61 (2013) 188; (f) Marchetti, F.; Pampaloni, G.; Zacchini, S. Dalton Trans. 42 (2013) 15226; (g) Dolci, S.; Marchetti, F.; Pampaloni, G.; Zacchini, S. Dalton Trans. 39 (2010) 5367.

[6] (a) Cotton, F. A.; Wilkinson, G.; Murillo, C. A.; Bochmann, M. Advanced Inorganic Chemistry, 6th ed.; John Wiley, Sons: New York, 1999; (b) Wu, Y.-T.; Ho, Y.-C.; Lin, C.C.; Gau, H.-M. Inorg. Chem. 35 (1996) 5948; (c) Ault, B. S.; Everhart, J. B. J. Phys. Chem. 100 (1996) 15726.

[7] (a) Klejnot, O. J. Inorg. Chem. 4 (1965) 1668; (b) Rillema, D. P.;. Reagan, W. J.; Brubaker Jr., C. H. Inorg. Chem. 8 (1969) 587; (c) Quignard, F.; Leconte, M.; Basset, J.-M.; Hsu, L.Y.; Alexander, J. J.; Shore, S. G. Inorg. Chem. 26 (1987) 4272.

[8] Glenny, M. W.; Nielson, A. J.; Rickard, C. E. F. Polyhedron 17 (1998) 851.

[9] (a) Bradley, D. C.; Multani, R. K.; Wardlaw, W. J. Chem. Soc. (1958) 4647; (b) Kepert, D. L.; Mandyczewsky, R. J. Chem. Soc. (A) (1968) 530. 
[10] Bardina, N. V.; Bazhenova, T. A.; Lyssenko, K. A.; Antipin, M. Yu.; Shulga, Y. M.; Filina, T. A.; Shestakov, A. F. Mendeleev Commun. 16 (2006) 307.

[11] Coe, E. M.; Jones, C. J. Polyhedron 11 (1992) 3123.

[12] Reddy, Ch. R.; Madhavi, P. P.; Reddy, A. S. Tetrahedron Lett. 48 (2007) 7169.

[13] Limberg, C.; Parsons, S.; Downs, A. J.; Watkin, D. J. J. Chem. Soc., Dalton Trans. (1994) 1169.

[14] Limberg, C.; Boese, R.; Schiemenz, B. J. Chem. Soc., Dalton Trans. (1997) 1633.

[15] (a) Larson, M. L.; Moore, F. W. Inorg. Chem. 5 (1966) 801; (b) Mercer, M. J. Chem. Soc (A) (1969) 2019.

[16] Gibson, V. C.; Kee, T. P.; Shaw, A. Polyhedron 9 (1990) 2293.

[17] Decken, A.; Knapp, C.; Nikiforov, G. B.; Passmore, J.; Rautiainen, J. M.; Wang, X.; Zeng, X. Chem. Eur. J. 15 (2009) 6504.

[18] (a) Mahmoudkhani, A. H.; Langer, V. Acta Crystallogr. C 55 (1999) 1631; (b) de Renzi, A.; di Blasio, B.; Panunzi, A.; Pedone, C.; Vitagliano, A. Gazz. Chim. Ital. 106 (1976) 709; (c) Mahmoudkhani, A. H.; Langer, V. Acta Crystallogr. C 55 (1999) 1163; (d) Jones, H. A. Acta Crystallogr. B 24 (1968) 592.

[19] Allen, F. H.; Kennard, O.; Watson, D. G.; Brammer, L.; Orpen, A. G.; Taylor, R. J. Chem. Soc., Perkin Trans. 2 (1987) S1-S19.

[20] (a) Beck, J.; Kellner, M.; Kreuzinger, M. Z. Anorg. Allg. Chem. 628 (2002) 2656; (b) Baumann, A.; Beck, J. Z. Anorg. Allg. Chem. 624 (1998) 1725; (c) Beck, J.; Hengstmann, M. Z. Naturforsch. B 51 (1996) 1415; (d) Klinzing, P.; El-Kholi, A.; Müller, U.; Dehnicke, K. Z. Anorg. Allg. Chem. 569 (1989) 83.

[21] (a) Qiu, W.; Li, L.; Liu, J.; Zheng, X.; Fan, Y.; Sun, C.; Huang, Q.; Zhang, J. Eur. J. Solid State Inorg. Chem. 30 (1993) 1039; (b) Beck, J.; Koch, M. Z. Anorg. Allg. Chem. 630 
(2004) 394-398; (c) Chang, Y.-D.; Zubieta, J. Inorg. Chim. Acta 245 (1996) 177; (d) Rabe, S.; Müller, U. Z. Anorg. Allg. Chem. 626 (2000) 12; (e) Beck, J.; Hengstmann, M. Z. Anorg. Allg. Chem. 624 (1998) 1943.

[22] (a) Blake, A. J.; Parsons, S.; Downs, A. J.; Limberg, C. Acta Crystallogr. C 51 (1995) 571;

(b) Garner, C. D.; Hill, L. H.; Mabbs, F. E.; McFadden, D. L.; McPhail, A. T. J. Chem. Soc., Dalton Trans. (1977) 853; (c) Beck, J.; Koch, M. Z. Anorg. Allg. Chem. 632 (2006) 756; (d) Knopp, B.; Lörcher, K.-P.; Strähle, J. Z. Naturforsch. B 32 (1977) 1361.

[23] Herbst-Irmer, R.; Egert, E. Acta Crystallogr. C 48 (1992) 1843.

[24] (a) Cordero, B.; Gómez, V.; Platero-Prats, A. E.; Revés, M.; Echevarría, J.; Cremades, E.; Barragán, F.; Alvarez, S. Dalton Trans. (2008) 2832; (b) Bondi, A. J. Phys. Chem. 68 (1964) 441.

[25] Skoog, D. A.; West, D. M.; Holler, F. J.; Crouch, S. R. Fundamentals of Analytical Chemistry, 8th Edition, Thomson Learning Inc, Belmont, CA, 2004.

[26] Crouthamel, C. E.; Johnson, C. E. Anal. Chem. 26 (1954) 1284.

[27] Sheldrick, G. M. SHELX97-Program for the refinement of Crystal Structures, University of Göttingen, Germany (1997). 


\section{SCHEME 1}

Reaction of $\mathrm{MoCl}_{5}$ with $\mathrm{N}, \mathrm{N}$-dimethylethanolamine.

$\mathrm{MoCl}_{5} \underset{\mathrm{Me}_{2} \mathrm{NCH}_{2} \mathrm{CH}_{2} \mathrm{OH}}{\mathrm{CH}_{2} \mathrm{Cl}_{2} \text {, r.t. }}\left[\mathrm{Me}_{2} \mathrm{NHCH}_{2} \mathrm{CH}_{2} \mathrm{Cl}_{2}\left[\mathrm{Mo}_{2} \mathrm{O}_{2} \mathrm{Cl}_{8}\right]\right.$

\section{SCHEME 2}

Molybdenum species derived from the reaction of $\mathrm{MoCl}_{5}$ with 2-methoxyethanol.

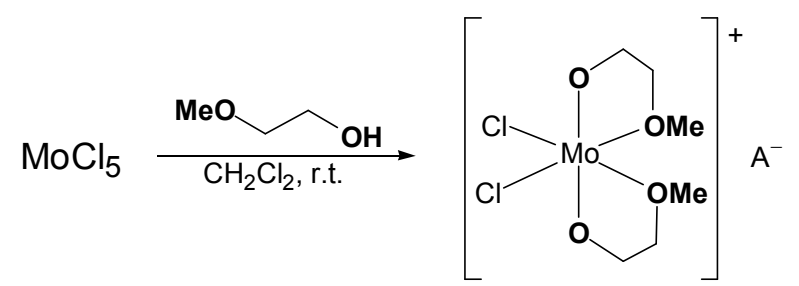

$$
\mathrm{A}^{-}=\left[\mathrm{Mo}_{2} \mathrm{O}_{2} \mathrm{Cl}_{7}\right]^{-}, \mathbf{2 a} ;\left[\mathrm{MoOCl}_{4}\right]^{-}, \mathbf{2 b}
$$

\section{SCHEME 3}

Degradation pathways of 2-methoxyethanol by interaction with $\mathrm{MoCl}_{5}$.

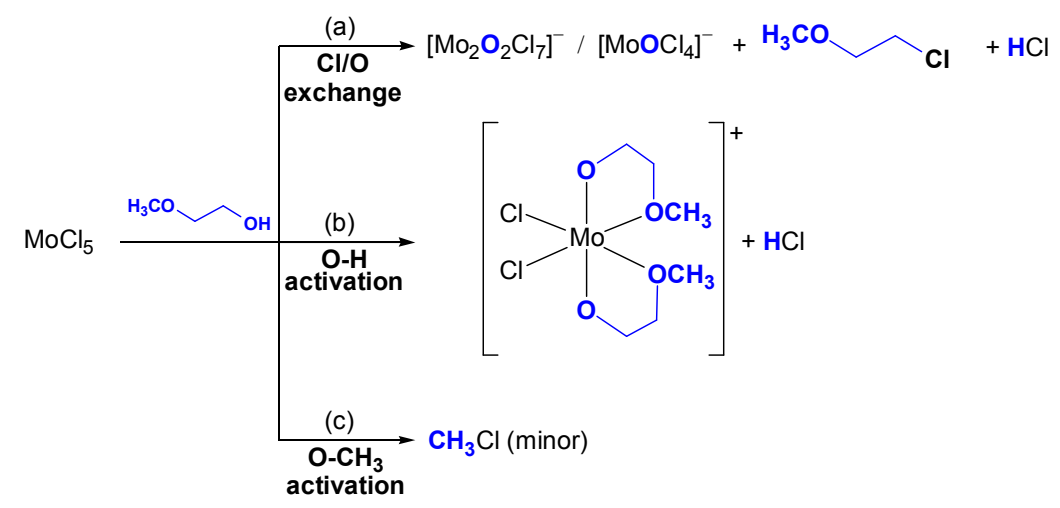




\section{Captions for Figures and Tables}

Figure 1. View of the molecular structures of $(a)$ the $\left[\mathrm{Me}_{2} \mathrm{NH}\left(\mathrm{CH}_{2}\right)_{2} \mathrm{Cl}\right]^{+}$cation and $(b)$ the $\left[\mathrm{Mo}_{2} \mathrm{O}_{2} \mathrm{Cl}_{8}\right]^{2-}$ anion of $\mathbf{1}$, with key atoms labeled. Atoms labeled as $\mathrm{Mo}\left(1_{-} 1\right)$, $\mathrm{Cl}\left(1 \_1\right), \mathrm{Cl}\left(2 \_1\right), \mathrm{Cl}\left(3 \_1\right), \mathrm{Cl}\left(4 \_1\right)$ and $\mathrm{O}\left(1 \_1\right)$ have been generated by symmetry operation $-\mathrm{x}, 1-\mathrm{y}, 1-\mathrm{z}$. Displacement ellipsoids are at the 50\% probability level..

Figure 2. View of the structures of $(a)$ the $\left[\mathrm{Mo}\left(\kappa^{2} O, O^{\prime}-\mathrm{O}\left(\mathrm{CH}_{2}\right)_{2} \mathrm{OMe}\right)_{2} \mathrm{Cl}_{2}\right]^{+}$cation and $(b)$ the $\left[\mathrm{Mo}_{2} \mathrm{O}_{2} \mathrm{Cl}_{7}\right]^{-}$anion of $\mathbf{2 a}$, with key atoms labeled. Displacement ellipsoids are at the $50 \%$ probability level.

Figure 3. View of the molecular structures of $(a)$ the $\left[\mathrm{Mo}\left(\kappa^{2} O, O^{\prime}-\mathrm{O}\left(\mathrm{CH}_{2}\right)_{2} \mathrm{OMe}\right)_{2} \mathrm{Cl}_{2}\right]^{+}$ cation and $(b)$ the $\left[\mathrm{MoOCl}_{4}\right]^{-}$anion of $\mathbf{2} \mathbf{b}$, with key atoms labeled. Displacement ellipsoids are at the $50 \%$ probability level.

Figure 4. View of the interaction between two $\left[\mathrm{MoOCl}_{4}\right]^{-}$anions in $\mathbf{2 b}$ (yellow, Mo; green, $\mathrm{Cl}$; red, O). Weak $\mathrm{Mo} \cdots \mathrm{Cl}$ contacts $[2.956(2) \AA]$ are represented as dashed lines.

Table 1. Selected bond lengths $(\AA)$ and angles $\left(^{\circ}\right)$ for $\mathbf{1}$.

Table 2. Selected bond lengths $(\AA)$ and angles $\left(^{\circ}\right)$ for $\mathbf{2 a}$.

Table 3. Selected bond lengths $(\AA)$ and angles $\left(^{\circ}\right)$ for $\mathbf{2 b}$.

Table 4. Crystal data and details of the structure refinement for $\left[\mathrm{Me}_{2} \mathrm{NH}\left(\mathrm{CH}_{2}\right)_{2} \mathrm{Cl}\right]_{2}\left[\mathrm{Mo}_{2} \mathrm{O}_{2} \mathrm{Cl}_{8}\right], \mathbf{1}, \quad\left[\mathrm{Mo}\left(\kappa^{2}-\mathrm{O}\left(\mathrm{CH}_{2}\right)_{2} \mathrm{OMe}\right)_{2} \mathrm{Cl}_{2}\right]\left[\mathrm{Mo}_{2} \mathrm{O}_{2} \mathrm{Cl}_{7}\right], \mathbf{2 a}$, and $\left[\mathrm{Mo}\left(\kappa^{2}-\mathrm{O}\left(\mathrm{CH}_{2}\right)_{2} \mathrm{OMe}\right)_{2} \mathrm{Cl}_{2}\right]\left[\mathrm{MoOCl}_{4}\right] \cdot \mathrm{CH}_{2} \mathrm{Cl}_{2}, \mathbf{2 b} \cdot \mathrm{CH}_{2} \mathrm{Cl}_{2}$. 


\section{TABLES}

\section{Table 1}

\begin{tabular}{llll}
\hline $\mathrm{Mo}(1)-\mathrm{O}(1)$ & $1.6513(17)$ & $\mathrm{Mo}(1)-\mathrm{Cl}(1)$ & $2.3456(6)$ \\
$\mathrm{Mo}(1)-\mathrm{Cl}(2)$ & $2.3753(6)$ & $\mathrm{Mo}(1)-\mathrm{Cl}(3)$ & $2.3944(6)$ \\
$\mathrm{Mo}(1)-\mathrm{Cl}(4)$ & $2.3631(6)$ & $\mathrm{Mo}(1)-\mathrm{Cl}\left(3 \_1\right)$ & $2.866(2)$ \\
$\mathrm{N}(1)-\mathrm{C}(2)$ & $1.501(3)$ & $\mathrm{N}(1)-\mathrm{C}(3)$ & $1.490(3)$ \\
$\mathrm{N}(1)-\mathrm{C}(4)$ & $1.492(3)$ & $\mathrm{C}(1)-\mathrm{C}(2)$ & $1.510(3)$ \\
$\mathrm{C}(1)-\mathrm{Cl}(5)$ & $1.790(2)$ & & \\
& & & \\
$\mathrm{Cl}(2)-\mathrm{Mo}(1)-\mathrm{Cl}(4)$ & $166.38(2)$ & $\mathrm{Cl}(1)-\mathrm{Mo}(1)-\mathrm{Cl}(3)$ & $157.00(2)$ \\
$\mathrm{O}(1)-\mathrm{Mo}(1)-\mathrm{Cl}(3-1)$ & $176.63(5)$ & $\mathrm{Cl}(3)-\mathrm{Mo}(1)-\mathrm{Cl}\left(3 \_1\right)$ & $76.93(2)$ \\
$\mathrm{O}(1)-\mathrm{Mo}(1)-\mathrm{Cl}(1)$ & $103.08(6)$ & $\mathrm{Mo}(1)-\mathrm{Cl}(3)-\mathrm{Mo}\left(1 \_1\right)$ & $103.07(2)$ \\
$\mathrm{C}(2)-\mathrm{N}(1)-\mathrm{C}(3)$ & $113.18(17)$ & $\mathrm{C}(2)-\mathrm{N}(1)-\mathrm{C}(4)$ & $109.32(18)$ \\
$\mathrm{C}(3)-\mathrm{N}(1)-\mathrm{C}(4)$ & $110.51(18)$ & $\mathrm{N}(1)-\mathrm{C}(2)-\mathrm{C}(1)$ & $113.89(18)$ \\
$\mathrm{C}(2)-\mathrm{C}(1)-\mathrm{Cl}(5)$ & $111.37(15)$ & & \\
\hline $\mathrm{Sy} m \mathrm{~m}$ & & & \\
\hline
\end{tabular}

$\overline{\text { Symmetry transformation used to generate equivalent atoms: }-\mathrm{x}, 1-\mathrm{y}, 1}-\mathrm{z}$

\section{Table 2}

\begin{tabular}{llll}
\hline $\mathrm{Mo}(1)-\mathrm{Cl}(1)$ & $2.282(2)$ & $\mathrm{Mo}(1)-\mathrm{Cl}(2)$ & $2.271(2)$ \\
$\mathrm{Mo}(1)-\mathrm{O}(1)$ & $1.828(5)$ & $\mathrm{Mo}(1)-\mathrm{O}(2)$ & $2.216(5)$ \\
$\mathrm{Mo}(1)-\mathrm{O}(3)$ & $1.816(5)$ & $\mathrm{Mo}(1)-\mathrm{O}(4)$ & $2.207(5)$ \\
$\mathrm{C}(1)-\mathrm{O}(1)$ & $1.438(9)$ & $\mathrm{C}(2)-\mathrm{O}(2)$ & $1.456(9)$ \\
$\mathrm{C}(4)-\mathrm{O}(3)$ & $1.457(9)$ & $\mathrm{C}(5)-\mathrm{O}(4)$ & $1.449(9)$ \\
$\mathrm{C}(3)-\mathrm{O}(2)$ & $1.451(9)$ & $\mathrm{C}(6)-\mathrm{O}(4)$ & $1.462(9)$ \\
$\mathrm{C}(1)-\mathrm{C}(2)$ & $1.505(12)$ & $\mathrm{C}(4)-\mathrm{C}(5)$ & $1.509(12)$ \\
$\mathrm{Mo}(2)-\mathrm{Cl}(3)$ & $2.301(2)$ & $\mathrm{Mo}(3)-\mathrm{Cl}(9)$ & $2.299(2)$ \\
$\mathrm{Mo}(2)-\mathrm{Cl}(4)$ & $2.322(2)$ & $\mathrm{Mo}(3)-\mathrm{Cl}(8)$ & $2.320(2)$ \\
$\mathrm{Mo}(2)-\mathrm{O}(6)$ & $1.661(5)$ & $\mathrm{Mo}(3)-\mathrm{O}(5)$ & $1.633(7)$ \\
$\mathrm{Mo}(2)-\mathrm{Cl}(5)$ & $2.772(2)$ & $\mathrm{Mo}(3)-\mathrm{Cl}(5)$ & $2.423(2)$ \\
$\mathrm{Mo}(2)-\mathrm{Cl}(6)$ & $2.4096(19)$ & $\mathrm{Mo}(3)-\mathrm{Cl}(6)$ & $2.777(2)$ \\
$\mathrm{Mo}(2)-\mathrm{Cl}(7)$ & $2.482(2)$ & $\mathrm{Mo}(3)-\mathrm{Cl}(7)$ & $2.489(2)$ \\
& & & \\
$\mathrm{Cl}(1)-\mathrm{Mo}(1)-\mathrm{O}(4)$ & $172.20(14)$ & $\mathrm{Cl}(2)-\mathrm{Mo}(1)-\mathrm{O}(2)$ & $173.10(15)$ \\
$\mathrm{O}(1)-\mathrm{Mo}(1)-\mathrm{O}(3)$ & $148.9(2)$ & $\mathrm{Cl}(1)-\mathrm{Mo}(1)-\mathrm{Cl}(2)$ & $94.93(8)$ \\
$\mathrm{O}(1)-\mathrm{Mo}(1)-\mathrm{O}(2)$ & $74.5(2)$ & $\mathrm{O}(3)-\mathrm{Mo}(1)-\mathrm{O}(4)$ & $75.0(2)$ \\
$\mathrm{O}(6)-\mathrm{Mo}(2)-\mathrm{Cl}(5)$ & $169.4(2)$ & $\mathrm{O}(5)-\mathrm{Mo}(3)-\mathrm{Cl}(6)$ & $168.4(3)$ \\
$\mathrm{Cl}(4)-\mathrm{Mo}(2)-\mathrm{Cl}(6)$ & $159.17(8)$ & $\mathrm{Cl}(8)-\mathrm{Mo}(3)-\mathrm{Cl}(5)$ & $158.93(8)$ \\
$\mathrm{Cl}(3)-\mathrm{Mo}(2)-\mathrm{Cl}(7)$ & $163.10(8)$ & $\mathrm{Cl}(9)-\mathrm{Mo}(3)-\mathrm{Cl}(7)$ & $162.12(8)$ \\
$\mathrm{Mo}(2)-\mathrm{Cl}(5)-\mathrm{Mo}(3)$ & $85.59(6)$ & $\mathrm{Mo}(2)-\mathrm{Cl}(6)-\mathrm{Mo}(3)$ & $85.75(6)$ \\
$\mathrm{Mo}(2)-\mathrm{Cl}(7)-\mathrm{Mo}(3)$ & $90.78(6)$ & & \\
\hline & & & \\
\hline
\end{tabular}

\section{Table 3}

\begin{tabular}{llcc}
\hline $\mathrm{Mo}(2)-\mathrm{Cl}(5)$ & $2.2896(14)$ & $\mathrm{Mo}(2)-\mathrm{Cl}(6)$ & $2.2909(13))$ \\
$\mathrm{Mo}(2)-\mathrm{O}(2)$ & $1.810(4)$ & $\mathrm{Mo}(2)-\mathrm{O}(3)$ & $2.184(3)$ \\
$\mathrm{Mo}(2)-\mathrm{O}(4)$ & $1.825(4)$ & $\mathrm{Mo}(2)-\mathrm{O}(5)$ & $2.201(4)$ \\
$\mathrm{C}(1)-\mathrm{O}(2)$ & $1.457(6)$ & $\mathrm{C}(2)-\mathrm{O}(3)$ & $1.460(7)$ \\
$\mathrm{C}(4)-\mathrm{O}(4)$ & $1.442(6)$ & $\mathrm{C}(5)-\mathrm{O}(5)$ & $1.457(6)$ \\
$\mathrm{C}(3)-\mathrm{O}(3)$ & $1.444(6)$ & $\mathrm{C}(6)-\mathrm{O}(5)$ & $1.439(6)$ \\
$\mathrm{C}(1)-\mathrm{C}(2)$ & $1.520(8)$ & $\mathrm{C}(4)-\mathrm{C}(5)$ & $1.504(7)$ \\
$\mathrm{Mo}(1)-\mathrm{Cl}(1)$ & $2.3529(14)$ & $\mathrm{Mo}(1)-\mathrm{Cl}(2)$ & $2.3648(13)$ \\
$\mathrm{Mo}(1)-\mathrm{Cl}(3)$ & $2.4099(14)$ & $\mathrm{Mo}(1)-\mathrm{Cl}(4)$ & $2.3489(13)$ \\
$\mathrm{Mo}(1)-\mathrm{O}(1)$ & $1.646(3)$ & & \\
& & & \\
$\mathrm{Cl}(5)-\mathrm{Mo}(2)-\mathrm{O}(3)$ & $174.53(11)$ & $\mathrm{Cl}(6)-\mathrm{Mo}(2)-\mathrm{O}(5)$ & $172.38(10)$ \\
$\mathrm{O}(2)-\mathrm{Mo}(2)-\mathrm{O}(4)$ & $147.59(16)$ & $\mathrm{Cl}(5)-\mathrm{Mo}(2)-\mathrm{Cl}(6)$ & $93.48(5)$ \\
$\mathrm{O}(2)-\mathrm{Mo}(2)-\mathrm{O}(3)$ & $75.25(15)$ & $\mathrm{O}(4)-\mathrm{Mo}(2)-\mathrm{O}(5)$ & $74.78(15)$ \\
$\mathrm{Cl}(1)-\mathrm{Mo}(1)-\mathrm{Cl}(3)$ & $157.27(5)$ & $\mathrm{Cl}(2)-\mathrm{Mo}(1)-\mathrm{Cl}(4)$ & $162.77(5)$ \\
$\mathrm{O}(1)-\mathrm{Mo}(1)-\mathrm{Cl}(1)$ & $101.69(14)$ & $\mathrm{O}(1)-\mathrm{Mo}(1)-\mathrm{Cl}(2)$ & $98.15(12)$ \\
$\mathrm{O}(1)-\mathrm{Mo}(1)-\mathrm{Cl}(3)$ & $101.02(14)$ & $\mathrm{O}(1)-\mathrm{Mo}(1)-\mathrm{Cl}(4)$ & $99.04(12)$ \\
\hline
\end{tabular}


Table 4

\begin{tabular}{|c|c|c|c|}
\hline Complex & 1 & $\mathbf{2 a}$ & $\mathbf{2 b} \cdot \mathrm{CH}_{2} \mathrm{Cl}_{2}$ \\
\hline Formula & $\mathrm{C}_{8} \mathrm{H}_{22} \mathrm{Cl}_{10} \mathrm{Mo}_{2} \mathrm{~N}_{2} \mathrm{O}_{2}$ & $\mathrm{C}_{6} \mathrm{H}_{14} \mathrm{Cl}_{9} \mathrm{Mo}_{3} \mathrm{O}_{6}$ & $\mathrm{C}_{6.5} \mathrm{H}_{15} \mathrm{Cl}_{7} \mathrm{Mo}_{2} \mathrm{O}_{5}$ \\
\hline Fw & 724.66 & 789.04 & 613.21 \\
\hline $\mathrm{T}, \mathrm{K}$ & $100(2)$ & $100(2)$ & $100(2)$ \\
\hline$\lambda, \AA$ & 0.71073 & 0.71073 & 0.71073 \\
\hline Crystal system & Monoclinic & Triclinic & Monoclinic \\
\hline Space group & $P 2_{1} / n$ & $P \overline{1}$ & $P 2 / c$ \\
\hline$a, \AA$ & $6.9628(10)$ & $7.4548(13)$ & $14.539(3)$ \\
\hline$b, \AA$ & $15.422(2)$ & $11.811(2)$ & $8.3676(15)$ \\
\hline$c, \AA$ & $11.1004(16)$ & $12.877(2)$ & $15.536(3)$ \\
\hline$\alpha,{ }^{\circ}$ & 90 & $84.063(2)$ & 90 \\
\hline$\beta,^{\circ}$ & $94.763(2)$ & $81.812(2)$ & $104.009(2)$ \\
\hline$\gamma,{ }^{\circ}$ & 90 & $86.778(2)$ & 90 \\
\hline Cell Volume, $\AA^{3}$ & $1187.9(3)$ & $1115.2(3)$ & $1833.9(6)$ \\
\hline $\mathrm{Z}$ & 2 & 2 & 4 \\
\hline$D_{c}, \mathrm{~g} \mathrm{~cm}^{-3}$ & 2.026 & 2.350 & 2.221 \\
\hline$\mu, \mathrm{mm}^{-1}$ & 2.187 & 2.757 & 2.398 \\
\hline $\mathrm{F}(000)$ & 708 & 754 & 1188 \\
\hline Crystal size, mm & $0.16 \times 0.13 \times 0.11$ & $0.16 \times 0.15 \times 0.12$ & $0.18 \times 0.16 \times 0.14$ \\
\hline$\theta$ limits, $^{\circ}$ & $2.27-27.87$ & $1.61-25.03$ & $1.44-26.00$ \\
\hline Reflections collected & 13416 & 9616 & 17757 \\
\hline Independent reflections & $2810\left[R_{\mathrm{int}}=0.0337\right]$ & $3849\left[R_{\mathrm{int}}=0.0264\right]$ & $3607\left[R_{\mathrm{int}}=0.0646\right]$ \\
\hline Data / restraints /parameters & $2810 / 1 / 112$ & $3849 / 0 / 217$ & $3607 / 0 / 186$ \\
\hline Goodness on fit on $\mathrm{F}^{2}$ & 1.014 & 1.056 & 1.093 \\
\hline$R_{1}(I>2 \sigma(I))$ & 0.0225 & 0.0556 & 0.0449 \\
\hline$w R_{2}$ (all data) & 0.0563 & 0.1854 & 0.1194 \\
\hline Largest diff. peak and hole, e $\AA^{-3}$ & $0.582 /-0.550$ & $4.037 /-1.344$ & $2.173 /-1.143$ \\
\hline
\end{tabular}


Figure 1

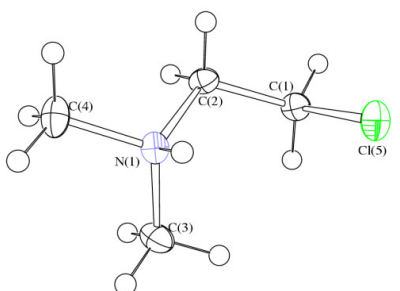

(a)

Figure 2

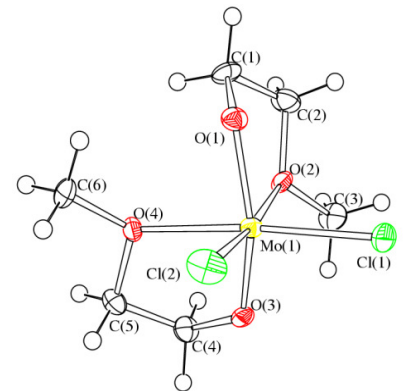

(a)

Figure 3

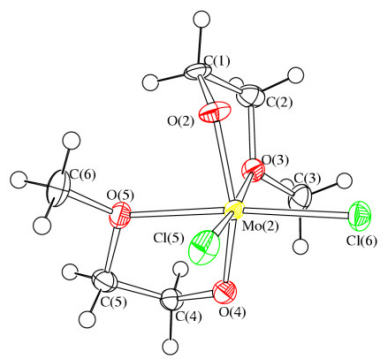

(a)

Figure 4

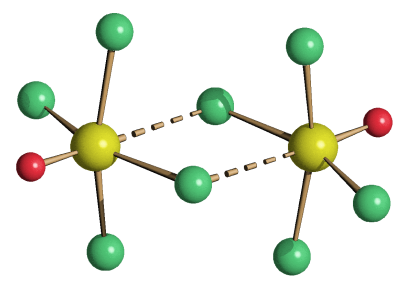

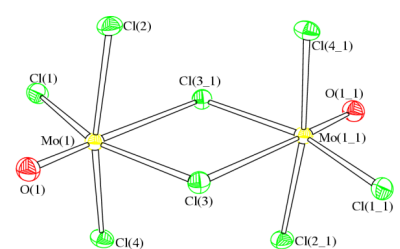

(b)

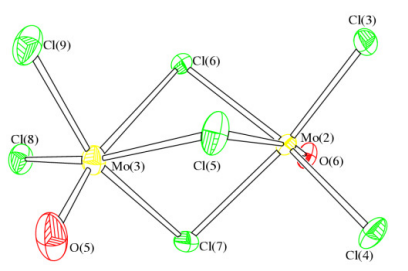

(b)

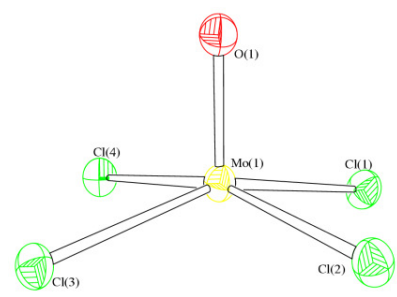

(b) 